University of Nebraska - Lincoln

DigitalCommons@University of Nebraska - Lincoln

Mammalogy Papers: University of Nebraska

State Museum

Museum, University of Nebraska State

2008

\title{
Characterization of a Contact Zone Between Two Subspecies of the Big Brown Bat (Eptesicus fuscus) in Nebraska
}

Justin D. Hoffman

University of Nebraska-Lincoln, jhoffman@mcneese.edu

Hugh H. Genoways

University of Nebraska - Lincoln, h.h.genoways@gmail.com

Follow this and additional works at: https://digitalcommons.unl.edu/museummammalogy

Part of the Zoology Commons

Hoffman, Justin D. and Genoways, Hugh H., "Characterization of a Contact Zone Between Two Subspecies of the Big Brown Bat (Eptesicus fuscus) in Nebraska" (2008). Mammalogy Papers: University of Nebraska State Museum. 146.

https://digitalcommons.unl.edu/museummammalogy/146

This Article is brought to you for free and open access by the Museum, University of Nebraska State at DigitalCommons@University of Nebraska - Lincoln. It has been accepted for inclusion in Mammalogy Papers: University of Nebraska State Museum by an authorized administrator of DigitalCommons@University of Nebraska Lincoln. 


\title{
CHARACTERIZATION OF A CONTACT ZONE BETWEEN TWO SUBSPECIES OF THE BIG BROWN BAT (EPTESICUS FUSCUS) IN NEBRASKA
}

\author{
Justin D. Hoffman ${ }^{1,2}$ and Hugh H. Genoways ${ }^{1}$
}

\begin{abstract}
Two subspecies of the big brown bat (Eptesicus fuscus) are reported to occur in Nebraska. The eastern race, E. f. fuscus, is reportedly bigger and darker than its western counterpart E. f. pallidus. Where these 2 subspecies come in contact is the subject of debate. We used external, cranial, and colorimetric data to investigate geographic variation among populations of E. fuscus in Nebraska to determine the location of the zone of contact between $E$. $f$. fuscus and E. f. pallidus. We discovered significant variation in external, cranial, and colorimetric data, suggesting that $E$. fuscus is represented by 2 subspecies in Nebraska. Our results showed that E. f. pallidus is smaller, possesses lighter pelage, and is restricted to the northern and western parts of Nebraska, whereas E. f. fuscus is larger, possesses darker pelage, and occurs in southern and southeastern parts of the state. Populations located between these regions represent intergrades of the 2 subspecies. We suggest that the subspecific boundary represents a broad zone of integration running in a northeast to southwest direction and may reflect the position of temperature and precipitation clines.
\end{abstract}

Key words: contact zone, Eptesicus fuscus fuscus, Nebraska, Eptesicus fuscus pallidus, subspecies, variation.

The position of subspecific boundaries among populations of the big brown bat (Eptesicus fuscus) generally is unclear throughout its geographic range. On the Great Plains, there are 2 recognized subspecies of the big brown bat (Hall 1981, Jones et al. 1983). The eastern race, E. f. fuscus, is larger and darker than the western subspecies E. f. pallidus (Burnett 1983a, Jones et al. 1983). Exactly where these 2 subspecies come in contact is the subject of debate. A number of studies place the zone of contact in the eastern third of the Dakotas and Nebraska, continuing southwestward into Kansas and Oklahoma (Long and Severson 1969, Hall 1981, Jones et al. 1983). Other studies suggest that the western subspecies, E. f. pallidus, is absent from the southern plains states of Kansas and Oklahoma and that the contact zone is located in the western portions of Nebraska and the Dakotas (Allen 1933, Engels 1936, Burnett 1983a, Choate et al. 1986, Caire et al. 1989).

In Nebraska, studies place the zone of contact between the 2 subspecies in the eastern third of Nebraska (Fig. 1). Jones (1964) noted that E. f. fuscus has much darker pelage than E. f. pallidus and that the 2 subspecies could be discerned easily based on color, although some variation within sites was observed. Czaplewski et al. (1979) also described E. f. fuscus as being darker and larger than E. f. pallidus. Data used in the above studies were limited geographically, with no specimens examined from the southwestern, central, or southeastern parts of the state. Subsequent collecting efforts have focused on these areas, resulting in a more complete data set. Thus, a reexamination of the geographic variation of E. fuscus in Nebraska is warranted. The objectives of our study were to (1) determine whether there are 2 subspecies of $E$. fuscus present in Nebraska and, if so, (2) determine the location of the zone of contact between the 2 recognized subspecies, based on the patterns of colorimetric and morphological variation.

\section{METHODS}

We examined 371 adult specimens of $E$. fuscus from Nebraska (Appendix). Specimens used in this study are housed at the University of Nebraska State Museum (UNSM), the University of Kansas Museum of Natural History $(\mathrm{KU})$, the University of Nebraska-Kearney Vertebrate Museum (VMKSC), the Museum of Southwestern Biology at the University of New Mexico (MSB), the Museum of Vertebrate Zoology at the University of California (MVZ), and the University of Michigan Museum of Zoology (UMMZ). Data were gathered from

\footnotetext{
${ }^{1}$ School of Natural Resources and University of Nebraska State Museum, W436 Nebraska Hall, University of Nebraska-Lincoln, Lincoln, NE 68588. 2E-mail: jhoffma3@bigred.unl.edu
} 
A.

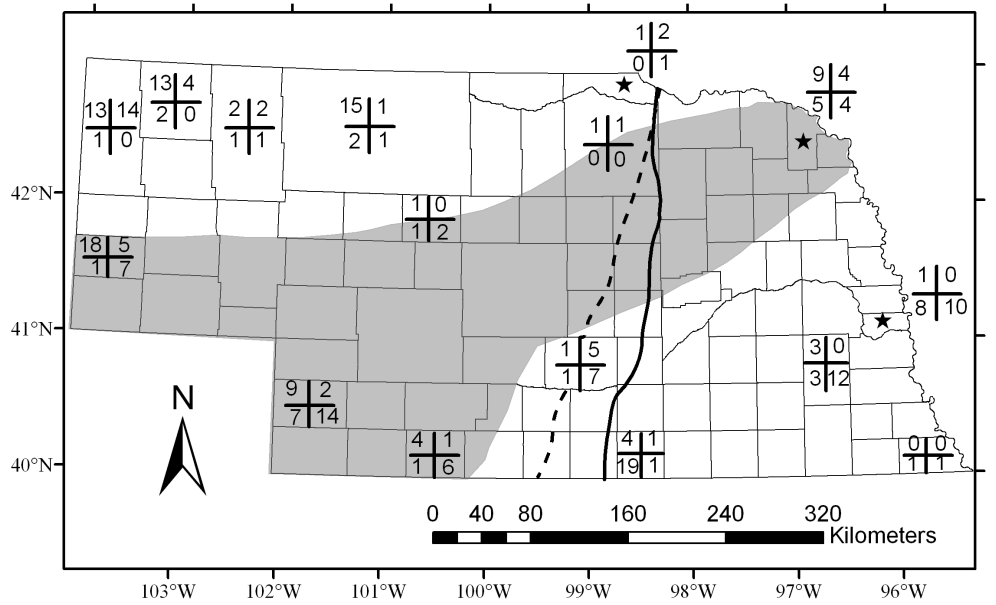

B.

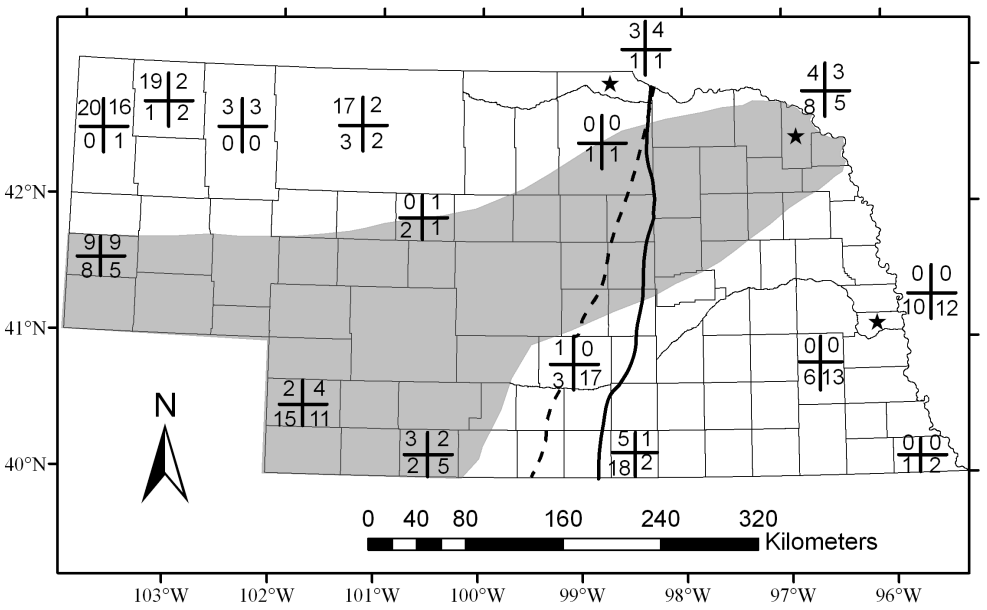

Fig. 1. Distribution of discriminant function results for morphology (A) and color (B). Matrices located inside the counties represent number of males (column 1) and females (column 2) that were assigned to Eptesicus fuscus pallidus (row 1) and E. f. fuscus (row 2) as determined by discriminant function analysis (DFA). Counties marked by stars correspond to adjacent matrices. The solid line represents the zone of contact between the 2 subspecies as determined by Jones (1964), and the dotted line represents the zone of contact as determined by Czaplewski et al. (1979). Based on data from the DFA, we considered populations to be outside the contact zone if more than half of both males and females were recognized as the same subspecies for both morphology and color. All other populations were placed within the contact zone (shaded area).

specimens collected in 16 counties and grouped into sample units that were used to analyze geographic variation (Fig. 1). These counties were chosen because large samples of big brown bats were collected from specific localities within these areas.

Morphological variation was assessed by measuring a standard set of cranial and external characters with a digital caliper and rounding to the nearest $0.1 \mathrm{~mm}$ : greatest length of skull (GLS), condylobasal length (CL), zygo- matic breadth (ZB), postorbital breadth (PB), mastoid breadth (MB), breadth across upper molars (M-M), length of maxillary toothrow (LMXT), length of mandibular toothrow (LMT), and forearm length (FA).

Pelage color was assessed from digital photographs (Nikon COOLPIX 5000) of the dorsum of each specimen. Red (R), blue (B), and green $(\mathrm{G})$ values were collected from approximately the middorsum of each specimen with the JPEG viewer in ArcMAP 9.0. To maintain 
TABLE 1. Means and standard deviations of external and cranial measurements ( $\mathrm{mm}$ ) of male and female Eptesicus fuscus in Nebraska, with ranges given in parentheses. The $F$-statistic from the ANOVA along with the significance level is given for each measurement.

\begin{tabular}{lcccc}
\hline Measurement & Males & Females & $F$ & $P$ \\
\hline Greatest length of skull & $18.3 \pm 0.6(16.7-19.9)$ & $18.8 \pm 0.6(17.0-21.0)$ & 54.614 & 0.0001 \\
Condylobasal length & $17.6 \pm 0.5(16.0-19.0)$ & $18.1 \pm 0.5(16.5-20.0)$ & 55.373 & 0.0001 \\
Zygomatic breadth & $12.3 \pm 0.6(10.1-13.4)$ & $12.6 \pm 0.5(10.7-14.4)$ & 26.525 & 0.0001 \\
Postorbital breadth & $4.2 \pm 0.1(3.8-4.7)$ & $4.3 \pm 0.1(3.9-4.9)$ & 3.441 & 0.064 \\
Mastoid breadth & $9.7 \pm 0.4(8.6-10.7)$ & $10.0 \pm 0.3(8.9-10.8)$ & 47.575 & 0.0001 \\
Width across upper molars & $7.9 \pm 0.3(7.2-8.7)$ & $8.1 \pm 0.3(7.1-9.0)$ & 1.681 & 0.196 \\
Length of maxillary toothrow & $5.2 \pm 0.1(4.7-5.7)$ & $5.3 \pm 0.2(4.9-5.8)$ & 15.276 & 0.0001 \\
Length of mandibular toothrow & $6.5 \pm 0.2(5.9-7.2)$ & $6.6 \pm 0.2(6.0-7.4)$ & 14.398 & 0.0001 \\
Length of forearm & $45.6 \pm 2.0(39.0-55.0)$ & $46.4 \pm 1.9(41.0-51.0)$ & 14.058 & 0.0001 \\
\hline
\end{tabular}

consistency among photographs, each was taken with a flash against a white background in rooms with fluorescent lighting. The digital camera was mounted on a tripod, and each specimen was placed $33 \mathrm{~mm}$ away from the lens. We programmed the camera to make consistent adjustments of color and brightness for each picture.

We performed descriptive statistics and analysis of variance (ANOVA) to determine the extent of secondary sexual variation. A multivariate analysis of variance (MANOVA) was used to detect differences between sampling units in both color and morphological variation. A principal components analysis (PCA) with a varimax rotation and a Kaiser stopping rule of 1 eigenvalue was used to investigate potential relationships in morphological and colorimetric variation among populations of E. fuscus. A discrimnant function analysis (DFA) with reference samples for $E$. $f$. pallidus (Sioux and Dawes counties) and E. $f$. fuscus (Lancaster and Sarpy counties) was used to separate unknown specimens into subspecies for all other sample units. Based on data from the DFA, we considered populations to be outside the contact zone if more than half of both males and females were recognized as the same subspecies for both morphology and color. All other populations were placed within the contact zone. Statistical analyses were performed using SPSS statistical software (SPSS, Inc. 2002).

\section{RESUlTS}

In populations of E. fuscus from Nebraska, there was significant secondary sexual variation between sexes (Table 1). For external and cranial variables, measurements of females averaged larger than males; and only 2 variables, postorbital breadth and width across upper molars, were not statistically significant between sexes. Based on these results, we analyzed males and females separately.

For males, all morphological variables in the MANOVA were significantly different among sample units except postorbital breadth $(F=$ $1.205, P>0.05)$, length of maxillary toothrow $(F=1.587, P>0.05)$, and length of forearm $(F=1.716, P>0.05)$. For females, all morphological variables were statistically different $(P<0.001)$. Color variables $(\mathrm{R}, \mathrm{G}, \mathrm{B})$ for both sexes were significant $(P<0.001)$ among sample units.

Two principal components were extracted from morphological data for both sexes (Table 2). For males, 2 principal components explained $68.8 \%$ of the variation, with the 1st principal component explaining $56.7 \%$ of the variation and the 2nd principal component explaining $12.1 \%$ of the variation. For females, 2 principal components explained $67.5 \%$ of the variation, with the 1st principal component explaining $56.2 \%$ and the 2nd principal component explaining $11.3 \%$ of the variation. The loading of variables along the components varied between the sexes. In males, most of the morphological variables were loaded heavily on the 1st principal component. Only postorbital breadth and length of forearm were weighted heavily on the 2nd principal component, with component weights of -0.666 and 0.754 , respectively. All of the length variables in females (greatest length of skull, condyobasal length, length of maxillary toothrow, length of mandibular toothrow, and forearm length) were highly and positively loaded on the 1st principal component, whereas all of the breadth variables (zygomatic breadth, postorbital breadth, mastoid 
TABLE 2. Principal component scores of external and cranial measurements for male and female Eptesicus fuscus in Nebraska. Measurements included greatest length of skull (GLS), condylobasal length (CL), zygomatic breadth (ZB), postorbital breadth $(\mathrm{PB})$, mastoid breadth $(\mathrm{MB})$, breadth across upper molars $(\mathrm{M}-\mathrm{M})$, length of maxillary toothrow (LMXT), length of mandibular toothrow (LMT), and length of forearm (FA).

\begin{tabular}{lccccc}
\hline & \multicolumn{2}{c}{ Males } & & \multicolumn{2}{c}{ Females } \\
\cline { 2 - 3 } \cline { 5 - 5 } Measurement & Principal component 1 & Principal component 2 & & Principal component 1 & Principal component 2 \\
\hline GLS & 0.904 & 0.110 & 0.170 & 0.805 & 0.471 \\
CL & 0.905 & 0.067 & 0.837 & 0.382 \\
ZB & 0.887 & -0.666 & 0.481 & 0.673 \\
PB & 0.405 & -0.019 & -0.085 & 0.763 \\
MB & 0.854 & -0.089 & 0.468 & 0.673 \\
M-M & 0.772 & -0.148 & 0.351 & 0.730 \\
LMXT & 0.717 & -0.021 & 0.610 & 0.451 \\
LMT & 0.734 & 0.754 & 0.617 & 0.487 \\
FA & 0.374 & & 0.739 & -0.122 \\
\hline
\end{tabular}

TABle 3. Principal component scores of the 1st principal component for color from male and female Eptesicus fuscus in Nebraska.

\begin{tabular}{lcc}
\hline Measurement & Males & Females \\
\hline Red & 0.973 & 0.944 \\
Green & 0.994 & 0.966 \\
Blue & 0.974 & 0.960 \\
\hline
\end{tabular}

breadth, breadth across upper molars) were highly and positively loaded on the 2 nd principal component (Table 2).

Both sexes of E. fuscus had similar patterns of color variation. Both PCAs extracted 1 principal component that explained $96.2 \%$ (males) and $91.5 \%$ (females) of the variation in color. All 3 color variables (R, G, B) were highly and positively loaded on the 1st principal component for both sexes (Table 3).

The DFA calculated 1 discriminant function for each sex that explained $100 \%$ of the morphological variation and was highly significant among males (Wilks' $\lambda=0.298, P<0.001$ ) and females (Wilks' $\lambda=0.464, P<0.001$ ). The discriminant function coefficients showed that greatest length of skull, condylobasal length, and zygomatic breadth were weighted heavily on discriminant functions for both sexes (Table 4). Reference samples for male $E$. f. fuscus and E. f. pallidus showed no overlap among their discriminant scores (Fig. 2a). The DFA predicted all 18 reference specimens of E. f. pallidus and all 22 reference specimens of E. f. fuscus correctly. However, there was some overlap among females, where 3 of 29 reference specimens for E. f. pallidus were identified as E.f. fuscus and 3 of 15 reference specimens for E. f. fuscus were identified as $E$. f. pallidus (Fig. 2b). The misidentified specimens were spread evenly among the reference samples $($ Sioux County $=2$, Dawes County $=$ 1 , Lancaster County $=2$, Sarpy County $=1$ ). These specimens were collected at the same time and location as others that were assigned correctly to their respective subspecies.

The DFA of color in males and females extracted 1 discriminant function that explained $100 \%$ of the variance. Each analysis was significant for males (Wilks' $\lambda=0.298, P<$ 0.001 ) and females (Wilks' $\lambda=0.294, P<$ $0.001)$. Blue was the only variable that was weighted heavily on the discriminant function for males, whereas both red and blue variables were highly and positively weighted for females (Table 5). Some overlap occurred among the reference samples of E. f. pallidus (Fig. 2c-d). The most overlap occurred in males, where 3 of 21 reference specimens of E. f. pallidus were identified as E.f.fuscus; and in females, only 1 of 40 reference specimens for E. f. pallidus was classified as E. $f$. fuscus. All reference specimens of female (25) and male (16) E. f. fuscus were classified correctly (Fig. $2 \mathrm{c}-\mathrm{d})$.

The morphological discriminant scores were applied to 70 unknown specimens of adult male E. fuscus, and the model predicted 46 as E. f. fuscus and 24 as E. f. pallidus. For females, discriminant scores were applied to 104 unknown adult female E. fuscus, with 67 identified as E. f. pallidus and 37 identified as E. $f$. fuscus. Considerable morphological overlap existed among sample units of unknown specimens. In Banner County, more than half of the females were identified as the eastern race, $E$. f. fuscus (Fig. 1a). In Chase and Red Willow 

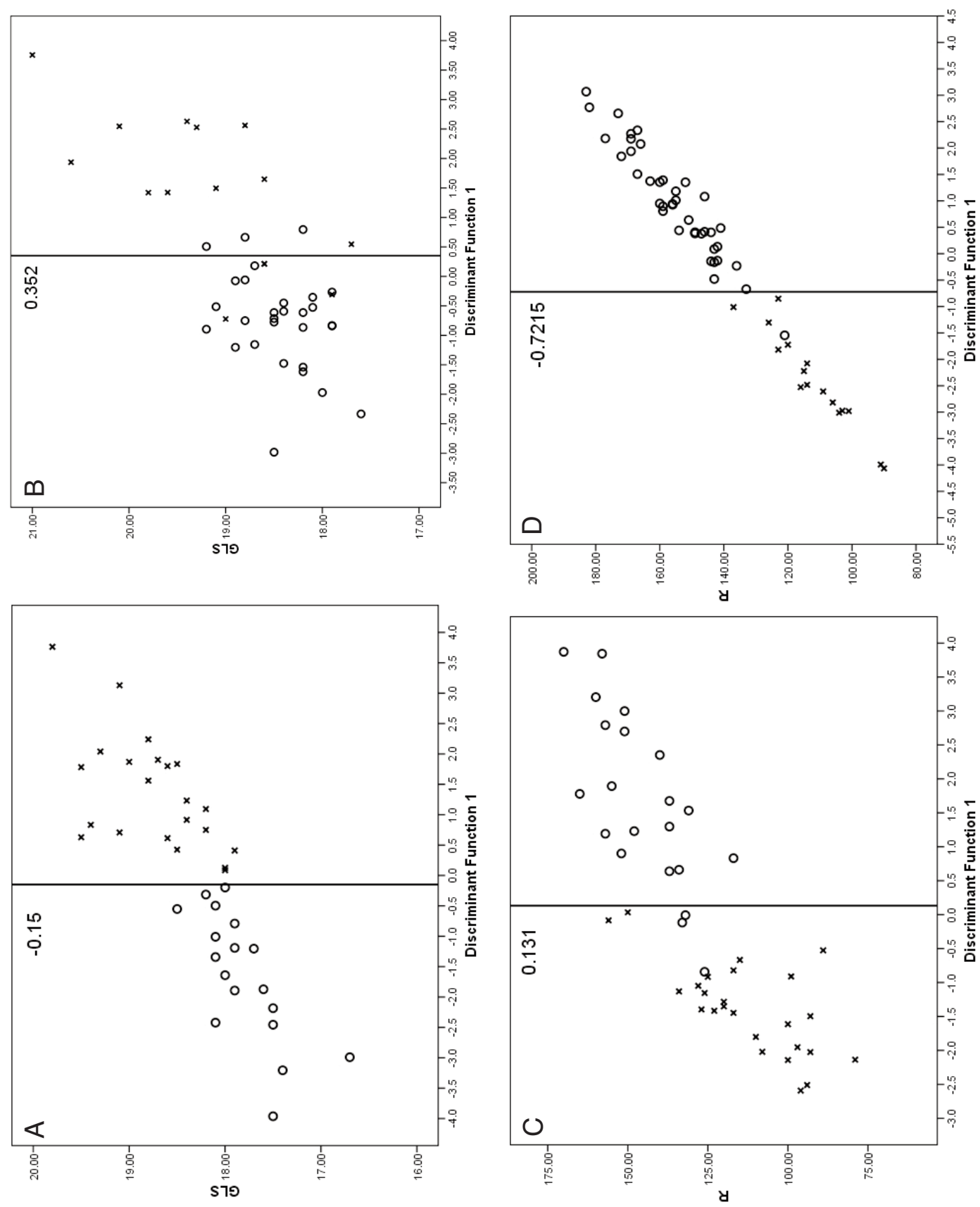

Fig. 2. Scatter plots of discriminant scores of known reference samples for Eptesicus fuscus: A, male morphology; B, female morphology; C, male color; D, female color. Circles represent E. f. pallidus, crosses represent E. f. fuscus, and vertical lines represent centroid dividers. Because only 1 discriminant function was calculated for each analysis, discriminant scores were plotted against red (R) values and greatest length of skull (GLS) to aid in visualization.

counties, females were predominately assigned to E. f. fuscus, whereas more males were referred to as E. f. pallidus (Fig 1a). In Dixon County, located in northeastern Nebraska, most males were assigned to E. f. pallidus, whereas females were evenly distributed between the 2 subspecies (Fig. la). Thomas County, located in north central Nebraska, is composed mostly 
TABLE 4. Standardized and unstandardized discriminant multipliers of external and cranial measurements for male and female Eptesicus fuscus in Nebraska. Measurements included greatest length of skull (GLS), condylobasal length $(\mathrm{CL})$, zygomatic breadth (ZB), postorbital breadth (PB), mastoid breadth (MB), breadth across upper molars (M-M), length of maxillary toothrow (LMXT), length of mandibular toothrow (LMT), and length of forearm (FA).

\begin{tabular}{lccrrr}
\hline & \multicolumn{2}{c}{ Males } & & \multicolumn{2}{c}{ Females } \\
\cline { 2 - 3 } Measurement & $\begin{array}{c}\text { Standardized } \\
\text { coefficient }\end{array}$ & $\begin{array}{c}\text { Unstandardized } \\
\text { coefficient }\end{array}$ & & $\begin{array}{c}\text { Standardized } \\
\text { coefficient }\end{array}$ & $\begin{array}{c}\text { Unstandardized } \\
\text { coefficient }\end{array}$ \\
\hline GLS & -0.710 & -1.614 & & 1.193 & -2.693 \\
CL & 1.061 & 2.511 & -1.440 & 3.811 \\
ZB & -0.347 & -1.987 & & 0.014 \\
PB & -0.157 & -0.473 & 0.002 & -0.154 \\
MB & 0.150 & -2.143 & -0.044 & -0.491 \\
M-M & -0.341 & 1.794 & -0.130 & -1.769 \\
LMXT & 0.344 & 0.164 & -0.370 & 1.785 \\
LMT & 0.274 & 1.411 & 0.367 & -0.102 \\
FA & 0.684 & -27.428 & -0.213 & -29.09 \\
Constant & - & & - & \\
\hline
\end{tabular}

TABLE 5. Standardized and unstandardized discriminant multipliers of color for male and female Eptesicus fuscus in Nebraska.

\begin{tabular}{lccccc}
\hline & \multicolumn{2}{c}{ Males } & & \multicolumn{2}{c}{ Females } \\
\cline { 2 - 3 } \cline { 5 - 6 } Measurement & $\begin{array}{c}\text { Standardized } \\
\text { coefficient }\end{array}$ & $\begin{array}{c}\text { Unstandardized } \\
\text { coefficient }\end{array}$ & & $\begin{array}{c}\text { Standardized } \\
\text { coefficient }\end{array}$ & $\begin{array}{c}\text { Unstandardized } \\
\text { coefficient }\end{array}$ \\
\hline Red & -0.247 & -0.015 & & 0.658 & 0.049 \\
Green & -0.301 & -0.021 & & -0.156 & -0.008 \\
Blue & 1.442 & -3.906 & - & 0.512 & -9.116 \\
Constant & - & & & - & \\
\hline
\end{tabular}

of E. f. fuscus, although all of the counties to the northwest and northeast contain populations dominated by E. f. pallidus (Fig. la).

Discriminant scores for color were applied to 86 unknown adult male and 110 unknown adult female E. fuscus. Fifty-three of the males and 63 of the females were classified as E. $f$. fuscus and 29 males and 47 females were classified as E.f. pallidus, respectively (Fig. 1b). Banner County had significant overlap in males and females (Fig 1b). In Chase and Red Willow counties, most individuals were referable to E. f. fuscus. This differed from morphological data where the majority of females were morphologically similar to E.f. pallidus. Dixon County had considerable overlap; however, in contrast to the morphological data, most of the specimens were assigned to E. f. fuscus based on color. Thomas County data showed that most specimens closely resembled E. f. fuscus.

\section{Discussion}

We observed secondary sexual variation in E. fuscus in Nebraska, with females being larger than males. Secondary sexual variation in $E$. fuscus has been noted in other studies. For example, Jones (1964) and Czaplewski et al. (1979) documented size differences of both sexes in Nebraska. For variation of E. fuscus across its geographic range, Burnett (1983a) noted significant differences between sexes except in interorbital breadth, a result which was similar to our findings (Table 1).

Larger size in females is common among vespertilionids (Williams and Findley 1979); however, the cause of this pattern is unresolved. Ralls (1976) proposed a "big-mother" hypothesis where she stated that larger females would be able to produce larger offspring and provide more food than smaller-sized females of the same species. Myers (1978) suggested that females are usually larger because of extra wing loading attributable to the extra mass present during pregnancy and lactation. Williams and Findley (1979) determined that secondary sexual dimorphism in vespertilionids is driven by increased energy demands during pregnancy because maintaining homothermy is more efficient for larger body sizes. In Nebraska, it is unclear which pattern is responsible for the observed secondary sexual variation; however, 
it seems possible that a combination of these factors is involved.

In general, both color and morphological measurements of E. fuscus have a similar distributional pattern across Nebraska (Fig. 1). Areas in southeastern Nebraska (Buffalo, Lancaster, Sarpy, Webster, and Richardson counties) are predominantly populated with individuals that are large and that have dark pelage. Areas located in northern and extreme western Nebraska (Boyd, Cherry, Dawes, Sheridan, and Sioux counties) are occupied by small and light-colored individuals. The remaining areas (Banner, Chase, Dixon, Holt, and Red Willow counties) have a large amount of overlap among individuals for size and color.

Variations in pelage color have also been observed among populations of E. fuscus in the Great Plains. Based on color, Jones and Genoways (1967) noted a zone of integration between the 2 subspecies somewhere between the 98th and 99th meridian in eastern South Dakota. In Kansas, Choate et al. (1986) quantified pelage color and discovered a westward trend of darker to lighter pelage. In Nebraska, both Jones (1964) and Czaplewski et al. (1979) used color as the primary basis for discerning the distribution of each subspecies. Our results are in accordance with previous studies in that significant variation in color exists among populations of E. fuscus in Nebraska (Fig 1b), but the pattern of variation follows a southeastnorthwest trend rather than an east-west trend.

The concept of variation in color patterns among populations of the same species has been well documented. Gloger's Rule was the 1st explanation for color variation; it states that the color of an individual's pelage correlates with humidity, with darker color morphs existing in more humid climates (Brown and Lomolino 1998). However, this hypothesis has gained little support. A more plausible explanation involves selection for color morphs that avoid detection by resembling the background of where they occur (Dice 1947, Kettlewell 1961). Thus, species in habitats where environmental backgrounds are of lighter colors, such as areas of sandy substrates and sparse vegetation, would possess individuals with pelages of lighter colors. Data extracted from the Nebraska STATSGO soil data (available from: http://csd.unl.edu/general/gis-datasets.asp \#Soils) show that there are loam and sandytextured soils in northern and northwestern
Nebraska where E. f. pallidus occurs. Precipitation in these areas is lower compared to southeastern Nebraska, with an average rainfall of $43.1 \mathrm{~cm}$ in the northwest compared to $76.2 \mathrm{~cm}$ in the southeast (HPRCC 2006). These conditions facilitate the presence of arid environments dominated by grasslands in the west and northwest as opposed to more moist forested areas of the east and southeast. This variation appears to be correlated with variation in color among populations of E. fuscus in Nebraska.

Based on these results, we conclude that 2 subspecies occur in Nebraska, with Eptesicus fuscus fuscus occurring in southeastern $\mathrm{Ne}-$ braska and E. f. pallidus occurring in northwestern Nebraska. Throughout central parts of the state, the subspecies meet in a broad zone of contact and intergradation (Fig. la-b). The fact that there is no abrupt step in the transition is not unexpected for mammalian subspecies. The orientation of this contact zone differs from that reported in the previous studies of Jones (1964) and Czaplewski et al. (1979). Similar to our results, Burnett (1983a) placed the zone of contact between populations of E. f. fuscus and E. f. pallidus running north-south approximately along the KansasColorado state line and then heading in a northeasterly direction through western $\mathrm{Ne}$ braska. He concluded that E.f. fuscus occurred in Kansas and in the central and eastern parts of Nebraska, whereas E.f. pallidus was limited to portions of northwestern Nebraska. For $E$. fuscus in Kansas, Choate et al. (1986) reported a gradual decreasing trend in size from east to west. Those authors determined that not enough evidence existed to support the recognition of 2 subspecies and that only E. f. fuscus was present in Kansas. Our results support the conclusions of Burnett (1983a) and Choate et al. (1986). We restrict E. f. pallidus as occurring primarily in the northern and western portions of Nebraska, and E. f. fuscus as occurring in southern and eastern Nebraska. Therefore, it is unlikely that many distinct individuals of E. f. pallidus, based both on light color and small size, would reach southward into northwestern Kansas.

The position of the subspecific boundary might be the result of climatic patterns in $\mathrm{Ne}$ braska. Burnett (1983b) assessed correlation of morphology in E. fuscus with climatic variables throughout its geographic range. He discovered 
that skull size was inversely related to temperature but directly related to moisture. He also noted that wing size was directly related to moisture, but that no significant relationship existed between wing size and temperature. Data from the High Plains Regional Climate Center (HPRCC) show that temperature and precipitation have a pronounced northwest to southeast transition in Nebraska (HPRCC 2006), with temperature and precipitation increasing in the southeastern part of the state. For example, Harrison, located in northwestern Nebraska (Sioux County), has an average annual temperature of $7.0^{\circ} \mathrm{C}$ and an average annual precipitation of $43.9 \mathrm{~cm}$. Auburn, located in southeastern Nebraska (Nemaha County), has an average annual temperature of $11.4^{\circ} \mathrm{C}$ and an average annual precipitation of $82.3 \mathrm{~cm}$. If variation in size of $E$. fuscus is correlated to temperature and precipitation, then the transition from larger to smaller individuals should resemble the climatic patterns present in Nebraska. Our results are somewhat contrary to the conclusions of Burnett (1983b), because in Nebraska, larger individuals inhabit areas with higher temperatures, indicating a direct, not an indirect, relationship between size and temperature. An explanation is that Burnett (1983b) examined specimens of E. fuscus throughout its entire geographic range, and his broad analysis might have concealed patterns of local variation. Burnett (1983b) did note a positive relationship between size and precipitation, which we also observed in Nebraska. This suggests that precipitation might be a better overall predictor of size in E. fuscus.

Much of the transition zone passes through central Nebraska where few specimens of $E$. fuscus were examined. Much of this area represents the Sandhills of Nebraska, which does not generally provide favorable habitat for crevice-roosting bats (Geluso 2006). For example, E. fuscus is known to roost in tree cavities and man-made structures (Jones 1964, Jones et al. 1983). Because of increased human settlement and fire suppression during the past century, more opportunities now exist for $E$. fuscus to colonize selected sites in the Sandhills. For example, Thomas County is located in the middle of the Sandhills and is bordered by populations of E. f. pallidus to the north; however, specimens examined from Thomas County, on average, resemble E. f. fuscus. All specimens examined from Thomas County were collected in the hand-planted Nebraska National Forest, established in 1902 (Manning and Geluso 1989, Geluso 2006). This area is bordered by the Middle Loup River to the north and the Dismal River to the south, both of which run in an east-west direction. As human settlement increased, wildfires were suppressed and grasslands gave way to woody riparian vegetation along rivers. These areas provide excellent dispersal corridors for several species, including bats (Benedict et al. 2000). For the big brown bat, we suggest that individuals moved westward along these riverine corridors until they encountered buildings located in the man-made forest or in nearby towns, which provided them suitable roosts. Although populations of E. f. pallidus are in close proximity (Cherry County), we would not expect individuals to readily disperse into Thomas County because of the absence of north-south dispersal corridors such as rivers with riparian forests.

Several other counties have unusual patterns of subspecies variation. Banner County is located in extreme western Nebraska and is surrounded by populations of $E$. f. pallidus; however, the sample from the county is not typical of the subspecies, especially with regard to pelage color. The reason for this atypical coloration of specimens from Banner County remains unclear, but 1 explanation could be the presence of the North Platte River. As in Thomas County, darker individuals representative of E.f. fuscus from eastern populations have likely used this corridor to disperse westward into the region. Conversely, in Dixon County, an eastern county, the individuals examined resembled the western subspecies, $E$. f. pallidus. Our results indicated that E. f. pallidus is restricted to woody areas of northern Nebraska, such as along the Niobrara River. Dixon County lies along the Missouri River not far from where the Niobrara River empties into the Missouri River. The proximity of Dixon County to the confluence of the 2 rivers may explain the variation present there. Other counties that have individuals that tend to be more intermediate between subspecies might be similarly affected by their proximity to natural dispersal corridors. An example is Buffalo County, which is located along the Platte River.

In conclusion, we agree with previous studies that 2 subspecies of E. fuscus occur in 
Nebraska, but we offer a different orientation and distribution for the populations. Populations occurring between these areas represent a broad zone of intergradation between the subspecies. We characterize the zone of transition as being broad and oriented in a northeast-southwest direction, which differs from the east-west orientation proposed by Jones (1964) and Czaplewski et al. (1979). The broad zone of contact indicates that these taxa are subspecies. If 2 distinct species existed, we would expect little or no overlap in morphology and color among specimens.

\section{ACKNOWLEDGMENTS}

Our work was funded by the University of Nebraska-Lincoln Initiative for Ecology and Evolutionary Analysis and the Center for Great Plains Studies. We thank the following institutions and their curators for allowing us to examine their specimens: Tom Labdez, University of Nebraska State Museum; Robert M. Timm, University of Kansas Museum of Natural History; Keith Geluso, University of Nebraska-Kearney Vertebrate Museum; Joseph A. Cook and Cindy A. Ramotnik, Museum of Southwestern Biology, University of New Mexico; James L. Patton and Christopher J. Conroy, Museum of Vertebrate Zoology, University of California; and Phillip Myers and Steve Hinshaw, University of Michigan, Museum of Zoology. We thank P.W. Freeman, University of Nebraska-Lincoln, for providing helpful comments on the grant proposal for this project. Finally, we thank Jerry R. Choate of the Sternberg Museum of Natural History and 1 anonymous reviewer for their suggestions on an earlier draft of the manuscript.

\section{Literature Cited}

AlLEN, G.M. 1933. Geographic variation in the big brown bat (Eptesicus fuscus). Canadian Field Naturalist 47:31-32

Benedict, R.A., H.H. Genoways, and P.W. Freeman. 2000. Shifting distributional patterns of mammals of Nebraska. Transactions of the Nebraska Academy of Sciences 26:55-84.

Brown, J.H., AND M.V. Lomolino. 1998. Biogeography. 2nd edition. Sinauer Associates, Inc., Sunderland, MA. $689 \mathrm{pp}$.

BurnetT, C.D. 1983a. Geographic and secondary sexual variation in the morphology of Eptesicus fuscus. Annals of the Carnegie Museum 52:139-161. 1983b. Geographic and climatic correlates of morphological variation in Eptesicus fuscus. Journal of Mammalogy 64:437-444.

Caire, W., J.D. Tyler, B.P. Glass, and M.A. Mares. 1989. Mammals of Oklahoma. University of Oklahoma Press, Norman. 567 pp.

Choate, J.R., J.W. Dragoo, J.K. Jones, JR., and J.A. Howard. 1986. Subspecific status of the big brown bat, Eptesicus fuscus, in Kansas. Prairie Naturalist 18:43-51.

Czaplewski, N.J., J.P. Farney, J.K. Jones, Jr., and J.D. DruECKER. 1979. Synopsis of bats of Nebraska. Occasional Papers, The Museum Texas Tech University 61:1-24.

Dice, L.R. 1947. Effectiveness of selection by owls of deer mice (Peromyscus maniculatus) which contrast in color with their background. Contribution, Laboratory Vertebrate Biology, University of Michigan $50: 1-5$.

ENGELS, W.L. 1936. Distribution of races of the brown bat (Eptesicus) in western North America. American Midland Naturalist 17:653-660.

Geluso, K. 2006. Bats in a human-made forest of central Nebraska. Prairie Naturalist 38:13-24.

HaLL, E.R. 1981. Mammals of North America. 2nd edition. John Wiley \& Sons, Inc., New York. 1175 pp.

[HPRCC] High Plains Regional Climate Center. 2006. Climate information products: 30 year normals [accessed 23 January 2007]. Available from: http://www .hprcc.unl.edu/products/normals.html

Jones, J.K., JR. 1964. Distribution and taxonomy of mammals of Nebraska. Publications of the Museum of Natural History, University of Kansas 16:1-356.

Jones, J.K., Jr., D.M. Armstrong, R.S. Hoffmann, And C. Jones. 1983. Mammals of the northern Great Plains. University of Nebraska Press, Lincoln. 375 pp.

Jones, J.K., JR., AND H.H. Genoways. 1967. Annotated checklist of bats from South Dakota. Transactions of the Kansas Academy of Sciences 70:184-196.

LONG, C.A., AND R.G. SEverson. 1969. Geographic variation in the big brown bat in the north-central United States. Journal of Mammalogy 50:621-624.

Kettlewell, H.B.D. 1961. The phenomenon of industrial melanisms in Lepidoptera. Annual Review of Ecology and Systematics 6:245-262.

Manning, R.W., and K.N. Geluso. 1989. Habitat utilization of mammals in a man-made forest in the Sandhill Region of Nebraska. Occasional Papers, The Museum Texas Tech University 131:1-34.

Myers, P. 1978. Sexual dimorphism in size of vespertilionid bats. American Naturalist 112:701-711.

RaLls, K. 1976. Mammals in which females are larger than males. Quarterly Review of Biology 51:245-276.

SPSS, INC. 2002. 11.0.0 for windows. SPSS, Inc., Chicago, IL.

Williams, D.F., and J.S. Findley. 1979. Sexual size dimorphism in vespertilionid bats. American Midland Naturalist 102:113-126.

Received 9 April 2007 Accepted 25 September 2007 
APPENDIX.-All known specimens of Eptesicus fuscus fuscus and E.f.pallidus from Nebraska used in analyses for this study. All individuals from counties in the contact zone with representatives of both subspecies were assigned to a single subspecies below, based on the subspecies with the majority of individuals from discriminant scores and geographic considerations. Specimens are housed in the University of Nebraska State Museum (UNSM), the University of Kansas Museum of Natural History (KU), the University of Nebraska-Kearney Vertebrate Museum (VMKSC), the Museum of Southwestern Biology at the University of New Mexico (MSB), the Museum of Vertebrate Zoology at the University of California (MVZ), and the University of Michigan Museum of Zoology (UMMZ). Within subspecies, localities are arranged alphabetically by county and then from northwest to southeast by reference location.

Eptesicus fuscus fuscus

Antelope Co.: Neligh, 1 (UMMZ). Buffalo Co.: Kearney, 24 (VMKSC). Chase Co.: Wauneta, 33 (UNSM). Dixon Co.: $1.1 \mathrm{mi} \mathrm{S}, 2.6 \mathrm{mi}$ E Homer, 3 (UNSM); Ponca State Park, 1 (UNSM); 3 mi N, 1 mi W Ponca, Ponca State Park, 8 (UNSM); $3 \mathrm{mi} \mathrm{N}$ Ponca, Ponca State Park, 5 (UNSM); $2.5 \mathrm{mi} \mathrm{N}, 0.75 \mathrm{mi}$ W Ponca, Ponca State Park, 4 (UNSM); 2.25 mi N Ponca, 1 (UNSM); $1 \mathrm{mi}$ W Maskell, 1 (UNSM); Wakefield, 2 (VMKSC). Harlan Co.: Alma, 2 (UNSM). Lancaster Co.: Lincoln, 19 (UNSM). Platte Co.: $1.5 \mathrm{mi} \mathrm{N}, 1 \mathrm{mi}$ W Columbus, 2 (VMKSC); Columbus, 20 (UNSM). Red Willow Co.: Indianola, 8 (UNSM); Indianola, 5 (VMKSC). Richardson Co.: $2.1 \mathrm{mi} \mathrm{S}, 3.4 \mathrm{mi}$ E Rulo, 1 (UNSM); 3 mi S, 5 mi E Rulo, 10 (UNSM). Sarpy Co.: cave near Grenta Fish Hatchery, 1 (UNSM); 1.5 mi NW Louisville, 3 (UNSM); 1 mi W Meadow, 1 (KU); 0.5 mi W Meadow, 6 (KU), $0.5 \mathrm{mi}$ W Meadow, 14 (UNSM); Meadow, 8 (UNSM). Thomas Co.: Nebraska National Forest, 4 (MSB). Webster Co.: $4.5 \mathrm{mi}$ E Red Cloud, 22 (KU); $4.5 \mathrm{mi}$ E Red Cloud, 4 (UNSM).

Eptesicus fuscus pallidus

Banner Co.: T20N, R54W, SE1/4 Sec. 25, 1 (UNSM); 10 mi S, 2.5 mi E Gering, 7 (VMKSC); 9 mi S, 5 mi E Harrisburg, 3 (KU); Wildcat Hills State Recreation Area, 23 (UNSM). Boyd Co.: 4 mi N, 2.5 mi W Spencer, 10 (KU). Cherry Co.: Fort Niobrara National Wildlife Refuge, 13 (MSB); Fort Niobrara National Wildlife Refuge, 1 (MVZ); Fort Niobrara National Wildlife Refuge, 7 (UNSM); 8 mi S, 0.5 mi W Nenzel, 3 (VMKSC); Valentine, 1 (KU). Dawes Co.: Bordeaux Creek, T32N, R48W, NE1/4 Sec. 14, 1 (UNSM); Chadron, 13 (UNSM); Chadron State Park, 3 (UNSM); 5.5 mi S, 4.25 mi E Chadron, 4 (UNSM); Coffee Mill Butte, T31N, R49W, SW1/4 Sec. 8, 6 (UNSM); T32N, R48W, Sec. 16, 1 (UNSM); T32N, R48W, SW1/4 Sec. 31, 1 (UNSM); T33N, R47W, SW1/4 Sec. 34, 1 (UNSM); T31N, R51W, NW1/4 Sec. 13, 1 (UNSM). Holt Co.: $5.1 \mathrm{mi} \mathrm{S}, 2 \mathrm{mi}$ E Spencer, 2 (UNSM). Sheridan Co.: T33N, R46W, SW1/4 of NE1/4 Sec. 13, Beaver Creek, 9 (UNSM); Metcalf Wildlife Management Area, 1 (UNSM); 15 mi N Rushville, 2 (KU); 13.7 mi N, 2 mi W, 3 (UNSM). Sioux Co.: T33N, R57W, NW1/4 Sec. 15, 1 (UNSM); T33N, R52W, SW1/4 Sec. 17, 1 (UNSM); T32N, R53W, SW1/4 Sec. 32, 1 (UNSM); Cook Ranch, Agate Springs, 7 (UNSM); $1.5 \mathrm{mi} \mathrm{N}, 11 \mathrm{mi}$ W Crawford, 3 (UNSM); $1 \mathrm{mi} \mathrm{N}, 8 \mathrm{mi}$ W, 2 (UNSM); $5.5 \mathrm{mi} \mathrm{W}$ Crawford, 11 (UNSM); $1 \mathrm{mi} \mathrm{S}, 4 \mathrm{mi}$ W Crawford, 4 (UNSM); Hudson-Meng site, NW Crawford, 2 (UNSM); 3 mi S Glen, 2 (UNSM); Woods Reserve, Trout Ponds, 6 (UNSM). 